\title{
Rapid Identification of Bioactive Compounds Reducing the Production of Amyloid $\beta$-Peptide $(A \beta)$ from South African Plants Using an Automated HPLC/SPE/HPLC Coupling System
}

\author{
Hak Cheol Kwon', Jin Wook Cha', Jin-Soo Park ${ }^{1}$, Yoon Sun Chun², Nivan Moodley ${ }^{3}$, Vinesh J. Maharaj ${ }^{3}$, \\ Sung Hee Youn ${ }^{2}$, Sungkwon Chung ${ }^{2, *}$ and Hyun Ok Yang ${ }^{1, *}$ \\ ${ }^{1}$ Natural Products Research Center, Korea Institute of Science and Technology, Gangneung 210-340, \\ ${ }^{2}$ Department of Physiology, Samsung Biomedical Research Institute, Sungkyunkwan University School of Medicine, Suwon 440-746, \\ Republic of Korea, \\ ${ }^{3}$ Biosciences, CSIR, RSA, PO Box 395, Pretoria, 0001, South Africa
}

\begin{abstract}
Automated HPLC/SPE/HPLC coupling experiments using the Sepbox system allowed the rapid identification of four bioactive principles reducing the production of amyloid $\beta$-peptide $(A \beta)$ from two South African plants, Euclea crispa subsp. crispa and Crinum macowanii. The structures of biologically active compounds isolated from the methanol extract of Euclea crispa subsp. crispa were assigned as 3-oxo-oleanolic acid (1) and natalenone (2) based on their NMR and MS data, while lycorine (3) and hamayne (4) were isolated from the dichloromethane-methanol (1:1) extract of Crinum macowanii. These compounds were shown to inhibit the production of $A \beta$ from HeLa cells stably expressing Swedish mutant form of amyloid precursor protein (APPsw).
\end{abstract}

Key Words: HPLC/SPE/HPLC, Alzheimer's disease, Amyloid $\beta$-peptide, Euclea crispa subsp. crispa, Crinum macowanii

\section{INTRODUCTION}

As one of the most serious health problems worldwide, $\mathrm{Al}$ zheimer's disease (AD) is the most common form of age-related dementia (Lim et al., 2006). Previously reported biochemical and genetic data have emerged to suggest that cerebral elevation, accumulation, or failure of clearance of amyloid $\beta$-peptide $(A \beta)$ causes synapse loss and neuronal injury in the pathogenesis of AD (Walsh and Selkoe, 2007). Sequential proteolytic cleavage of amyloid precursor protein (APP) by membrane bound $\beta$-, and $\gamma$-secretases produces two major isoforms of $A \beta, A \beta 40$ and $A \beta 42$. More amyloidogenic $A \beta 42$ is considered as a pathogenic agent (Iwatsubo et al., 1994). Even though there was great success in the understanding of $A D$, preventive drug is not available yet. Successful therapeutics for prevention or treatment of $A D$ require a potent compound that can efficiently antagonize AD-specific disease progression, i. e., reducing the production of $A \beta$ (Iwatsubo et al., 1994).

Herbal natural products are increasingly utilized by the general population worldwide, and continued to be a rich source of many novel therapeutic agents (John, 2009). However, the classical bioactivity-guided fractionation for the purification and identification of biologically active compounds from plants extracts can be tedious process with long time frames (Clarkson et al., 2006; Harvey, 2007). In addition, the bioassay during the bioactivity-guided fractionation may be obscured by poor solubility of samples or by fluorescent or colored substances in samples. A further complication can be synergistic activity of two constituents which may diminish or disappear upon separation ( $\mathrm{Li}$ et al., 2009). If the major target-compounds contained in crude extracts are identified in advance or earlier, the isolation efforts could be focused on truly bioactive components, avoiding repeated isolation of inactive or common constituents resulting in an increase in productivity and efficiency (Clarkson et al., 2006). The automated HPLC/ SPE/HPLC coupling experiments using a Sepbox system has the potential of providing the information of major target compounds by one step isolation from crude extracts. An extract can be fractionated into 100-300 substances composed of 1-4 compounds by this Sepbox system within less than 30 hours.

Euclea species has been used in African traditional medi- www.biomolther.org

Open Access DOI: 10.4062/biomolther.2011.19.1.090

pISSN: 1976-9148 elSSN: 2005-4483

Copyright $\odot 2011$ The Korean Society of Applied Pharmacology
Received Sep 24, 2010 Revised Dec 7, 2010 Accepted Dec 20, 2010

*Corresponding Author

E-mail: hoyang@kist.re.kr (Yang HO), schung@skku.edu (Chung SK) Tel: +82-33-650-3401 (Yang HO), +82-31-299-6103 (Chung SK) Fax: +82-33-650-3409 (Yang HO), +82-31-299-6129 (Chung SK) 
cine for hypnotics purpose or for alleviating toothache and headache (Joubert et al., 2006). Euclea species contain antimicrobial naphthoquinones and pentacyclic triterpernoids (Áurea Cruz Costa et al., 1976; Lall and Meyer, 2000; Schiaffella et al., 2000; Joubert et al., 2006). In particular, essential oils, saponins, terpenoid derivatives and alkaloids as well as flavonoids have been identified from Euclea crispa subsp. crispa (Pretorius et al., 2003).

Crinum macowanii Baker is widespread through the tropical and temperate regions of sub-Saharan Africa, and about 20 species of the genus Crinum (Amaryllidaceae) are endemic to southern Africa (Nair et al., 2000). C. macowanii has been used for the treatment of sexually-transmitted diseases and backache, or for lactation purpose in Zimbabwe and South Africa (Duri et al., 1994; Nair et al., 2000). The extracts of $C$. macowanii exhibited antiviral and antifungal effects against exotic RNA viruses and Candida albicans, respectively (Gundidza, 1986; Duri et al., 1994).

In the course of screening natural resources for small molecules that possess $A \beta$-lowering effects in vitro, we examined the inhibitors produced in the root of E. crispa subsp. crispa and the bulb of $C$. macowanii on the A $\beta 42$ formation in HeLa cells line stably expressing Swedish mutant form of APP (APPsw). During this survey, we isolated 3-oxo-oleanolic acid (1) and natalenone (2) from the methanolic extract of E. crispa subsp. crispa, and lycorine (3) and hamayne (4) from dichloromethane-methanol (1:1) extract of $C$. macowanii using the Sepbox system. These compounds 1-4 exhibited significant A $342-$ lowering (Fig. 1) activity in a dose-dependent manner. Here we first describe the $A \beta$ reducing effects of compounds 1-4 and rapid separation of these bioactive compounds using the automated HPLC/SPE/HPLC technique.

\section{MATERIALS AND METHODS}

\section{General experimental procedures}

The automated HPLC/SPE/HPLC coupling experiments was performed by using a Sepbox 2D-250 (Sepiatec $\mathrm{GmbH}$, Germany). Optical rotations were measured using a 35 polarimeter (PerkinElmer Co., USA). The NMR spectra were obtained on a Varian Unity Plus $500 \mathrm{MHz}$ NMR system (Varian Co., USA). Low-resolution ESIMS data were obtained on an Agilent $1200 \mathrm{HPLC} / \mathrm{MS}$ system (Agilent Co., USA). The analytical HPLC data was obtained on a YL9100 HPLC system (Younglin, Korea) equipped with YL9160 PDA detector, ELSD ZAM 3000 detector (Schambeck SFD, GmbH, Germany) and YLClarity version 3.0.2.222 data processing software. An Eclipse XDB C18 column $(4.6 \times 150 \mathrm{~mm}, 5 \mu \mathrm{m})$ was used for the analysis of fractions or compounds. Semi-preparative HPLC was performed using a Gilson 321 HPLC system (Gilson Co., France) with a UV/VIS-151 detector (254 nm) and a Shodex RI-101 refractive index detector. A Phenomenex Luna C18(2) column $(10 \times 250 \mathrm{~mm}, 10 \mu \mathrm{m})$ was used for the purification of fractions at a flow rate $4 \mathrm{ml} / \mathrm{min}$.

\section{Plant material}

The roots of Euclea crispa subsp. crispa were collected in the Lebombo mountains of KwaZuluNatal in South Africa. A voucher specimen (No. PRE841058.0) was deposited and identified at the South African National Biodiversity Institute (SANBI).

The bulbs of Crinum macowanii were collected on the coastal area of KwaZuluNatal in South Africa. A voucher specimen (No. 679627) was deposited and identified at the South African National Biodiversity Institute (SANBI).

\section{Plant extraction}

The roots and bulbs were separately cut into small pieces and dried in an oven at $30-60^{\circ} \mathrm{C}$ for 48 hours. Dried mate-

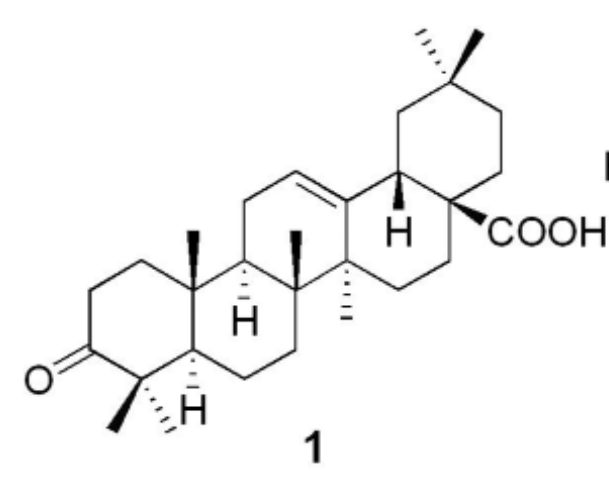<smiles></smiles><smiles>Cc1cc(O)c2c(c1)C(=O)C1=C(C2=O)[C@@H]2C[C@H]1C(=O)c1c(O)cc(C)cc12</smiles>

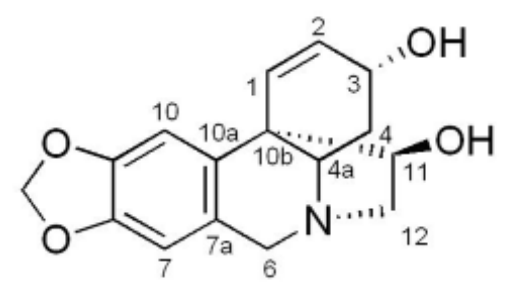

4
Fig. 1. The structures of compounds 1-4. (1) 3-oxo-oleanolic acid, (2) natalenone, (3) Lycorine, (4) Hamayne. 
rial was ground to a coarse powder using a hammer mill and stored at ambient temperature prior to extraction. The powdered plant material $(300 \mathrm{~g})$ was extracted either with dichloromethane (DCM):methanol $(\mathrm{MeOH})(1: 1)$, or $\mathrm{MeOH}$. After filtration, the organic extracts were concentrated using a rotary vacuum evaporator, and then further dried in vacuo at ambient temperature for 24 hours to give the methanol extract of Euclea crispa subsp. crispa (3.05 g) and DCM:MeOH (1:1) extract of Crinum macowanii $(1.6 \mathrm{~g})$. All extracts were stored at $-20^{\circ} \mathrm{C}$ prior to screening.

\section{Purification and isolation}

The methanol extract of E. crispa subsp. crispa (300 mg) was absorbed onto $\mathrm{C} 4$ reverse-phase resin $(800 \mathrm{mg})$ and packed in a stainless steel HPLC column $(10 \times 50 \mathrm{~mm})$. It was then subjected to Sepbox HPLC/SPE/HPLC coupling system equipped with UV (254 nm) and ELSD detectors using the separation conditions shown in Table 1 to obtain 98 subfractions. The subfractions SA28-30 and SA28-92 exhibited relatively significant $A \beta$-lowering effects (approximately $50 \%$ inhibition at $25 \mu \mathrm{g} / \mathrm{ml}$ ). The analyses of HPLC data revealed that the SA28-30 contained two compounds and SA28-92

Table 1. The fractionation conditions of the methanol extract of $E$. crispa subsp. crispa using the Sepbox system

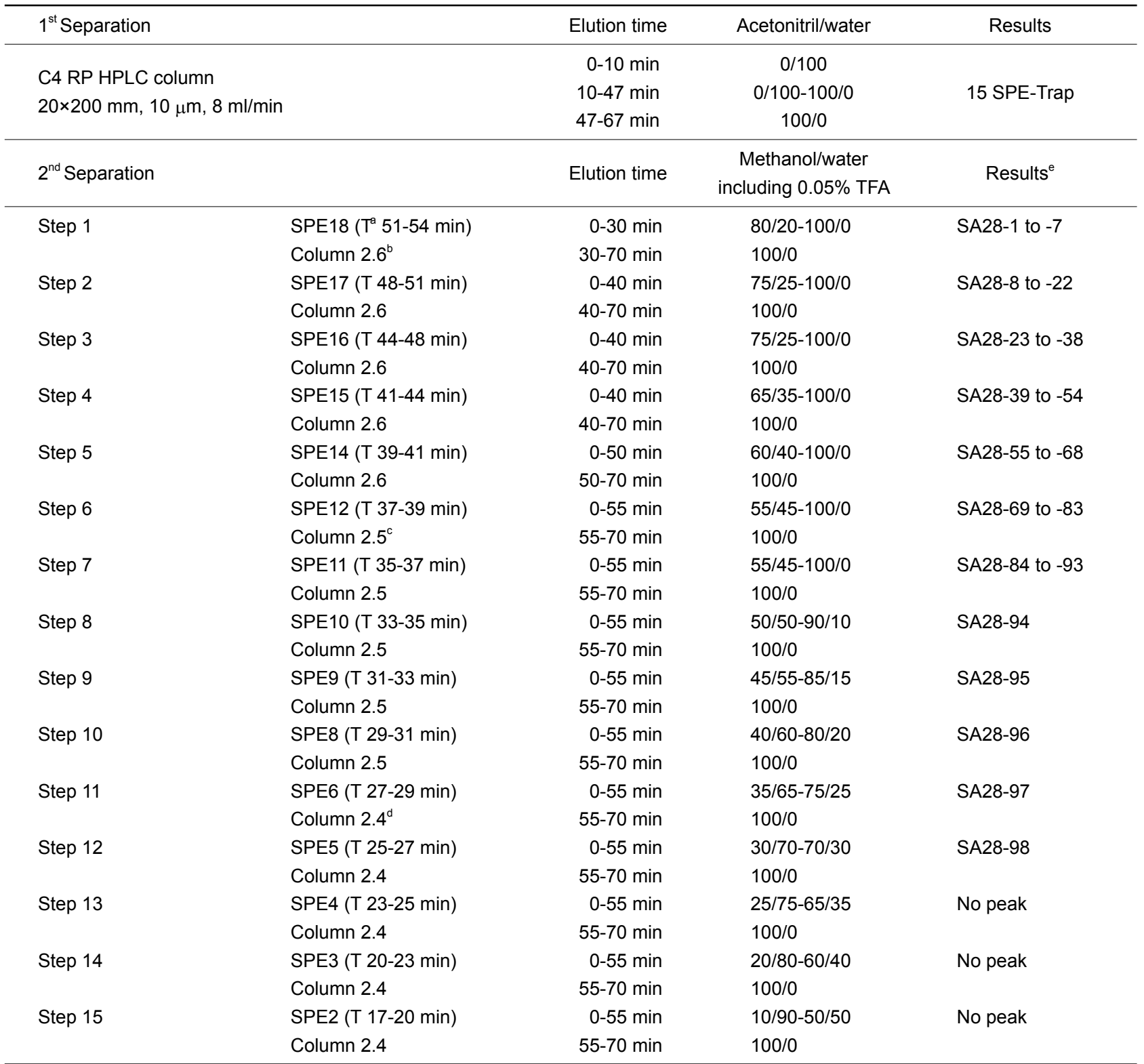

${ }^{\mathrm{a}} \mathrm{T}$ : Trapping time for the eluents from $1^{\text {st }}$ separation column, ${ }^{\mathrm{b}}$ Column 2.6 : C18 RP HPLC column $(10 \times 150 \mathrm{~mm}, 5 \mu \mathrm{m}, 3 \mathrm{ml} / \mathrm{min}),{ }^{\mathrm{c}} \mathrm{Column}$ 2.5: C18 RP HPLC column $(10 \times 250 \mathrm{~mm}, 5 \mu \mathrm{m}, 4 \mathrm{ml} / \mathrm{min}),{ }^{\mathrm{d} C o l u m n} 2.4$ : C18 Aqueous RP HPLC column $(10 \times 250 \mathrm{~mm}, 5 \mu \mathrm{m}, 4 \mathrm{ml} / \mathrm{min})$, ${ }^{\mathrm{e}}$ The eluents coming from $2^{\text {nd }}$ separation steps were collected in 48 deep well by $6 \mathrm{ml}$ using an automatic fraction collector, and the fractions were then manually re-arrayed into other 48 deep well plates through monitoring HPLC peaks from UV (254) and RI detectors. 
was composed of one major compound. The SA28-30 fraction was further purified by $\mathrm{C} 18$ reverse phase (RP) HPLC using a refractive index detector and a Phenomenex Luna C18 (2) column $(10 \times 250 \mathrm{~mm})$, eluting with a $90 \%$ methanol in water $(4$ $\mathrm{ml} / \mathrm{min}$ ) to afford betulin and compound $1(2 \mathrm{mg})$. Compound $2(0.5 \mathrm{mg})$ was obtained from the subfraction SA28-92 by $\mathrm{C} 18$ RP HPLC using a UV detector (254 nm), a Luna C18 (2) column $(10 \times 250 \mathrm{~mm})$ and a methanol-water gradient solvent system (70 to $80 \%$ for $40 \mathrm{~min}, 4 \mathrm{ml} / \mathrm{min}$ ).

The DCM-MeOH (1:1) extract of C. macowanii $(300 \mathrm{mg}$ ) was absorbed onto C4 reverse-phase resin $(800 \mathrm{mg})$ and packed in a stainless steel HPLC column $(10 \times 75 \mathrm{~mm})$. It was subjected to Sepbox purification using the separation conditions shown in Table 2 to obtain 33 subfractions. Two subfrac- tions SA20-17 and SA20-28 showed significant A $\beta$-lowering effects with approximately $70 \%$ inhibition at $25 \mu \mathrm{g} / \mathrm{ml}$. The fraction SA20-28 contained only one substance, compound 3 (1 $\mathrm{mg})$, and the fraction SA20-17 contained three substances as determined by HPLC analysis. The SA20-17 was further purified by $\mathrm{C} 18$ reverse phase (RP) HPLC using a UV detector (300 nm) and a Phenomenex Luna C18 (2) column (10×250 $\mathrm{mm}$ ), eluting with a $20 \%$ methanol in water containing a $0.02 \%$ trifluoroacetic ( $4 \mathrm{ml} / \mathrm{min}$ ) to obtain compound 3 and compound 4 (0.8 mg).

3-oxo-oleanoic acid (1): colorless powder. mp. $220^{\circ} \mathrm{C} ;[\alpha]_{D}{ }^{20}$ $+90^{\circ}\left(\mathrm{c} 0.5, \mathrm{CHCl}_{3}\right)$, ESI MS m/z $477[\mathrm{M}+\mathrm{Na}]^{+} ;{ }^{1} \mathrm{H}$ NMR (500 $\left.\mathrm{MHz}, \mathrm{CDCl}_{3}\right): \delta 0.83\left(3 \mathrm{H}, \mathrm{s}, \mathrm{H}_{3}-26\right), 0.92\left(3 \mathrm{H}, \mathrm{s}, \mathrm{H}_{3}-29\right), 0.95$ $\left(3 \mathrm{H}, \mathrm{s}, \mathrm{H}_{3}-30\right), 1.05\left(3 \mathrm{H}, \mathrm{s}, \mathrm{H}_{3}-24\right), 1.06\left(3 \mathrm{H}, \mathrm{s}, \mathrm{H}_{3}-25\right), 1.09$

Table 2. The fractionation conditions of the DCM-MeOH (1:1) extract of $C$. macowanii using the Sepbox system

\begin{tabular}{|c|c|c|c|c|}
\hline \multicolumn{2}{|c|}{$1^{\text {st }}$ Separation } & Elution time & Eluting solvents (Acetonitril/water) & Results \\
\hline \multirow{4}{*}{\multicolumn{2}{|c|}{$\begin{array}{l}\text { C4 RP HPLC column } \\
20 \times 200 \mathrm{~mm}, 10 \mu \mathrm{m}, 8 \mathrm{ml} / \mathrm{min}\end{array}$}} & $0-7 \min$ & $0 / 100$ & \multirow{4}{*}{17 SPE-Trap } \\
\hline & & $7-37 \mathrm{~min}$ & $0 / 100-50 / 50$ & \\
\hline & & $37-48 \mathrm{~min}$ & $50 / 50-100 / 0$ & \\
\hline & & $48-68 \min$ & $100 / 0$ & \\
\hline \multicolumn{2}{|c|}{$2^{\text {nd }}$ Separation } & Elution time & Eluting solvents & Results $^{g}$ \\
\hline Step 1 & SPE18 ( $\left.T^{\mathrm{a}} 51-54 \mathrm{~min}\right)$ & $0-20 \min$ & $\begin{array}{l}\text { Methanol/water }{ }^{d} \\
100 / 0\end{array}$ & SA20-1 \\
\hline Step 2 & SPE17 (T 48-51 min) & $0-20 \mathrm{~min}$ & $100 / 0$ & SA20-2 \\
\hline Step 3 & SPE16 (T 44-48 min) & $0-20 \mathrm{~min}$ & $100 / 0$ & SA20-3 \\
\hline Step 4 & SPE15 (T 41-44 min) & $0-10 \mathrm{~min}$ & $100 / 0$ & SA20-4 \\
\hline Step 5 & SPE14 (T 39-41 min) & $0-10 \mathrm{~min}$ & $100 / 0$ & SA20-5 \\
\hline Step 6 & SPE12 (T 37-39 min) & $0-10 \mathrm{~min}$ & $100 / 0$ & SA20-6 \\
\hline Step 7 & SPE11 (T 35-37 min) & $0-10 \mathrm{~min}$ & $100 / 0$ & SA20-7 \\
\hline Step 8 & SPE10 (T 33-35 min) & $0-10 \mathrm{~min}$ & $100 / 0$ & SA20-8 \\
\hline Step 9 & SPE9 (T 31-33 min) & $0-10 \mathrm{~min}$ & $100 / 0$ & SA20-9 \\
\hline Step 10 & SPE8 (T 29-31 min) & $0-10 \mathrm{~min}$ & $100 / 0$ & SA20-10 \\
\hline Step 11 & SPE6 (T 27-29 min) & $0-10 \mathrm{~min}$ & $100 / 0$ & SA20-11 \\
\hline Step 12 & SPE5 (T 25-27 min) & $0-10 \mathrm{~min}$ & $100 / 0$ & SA20-12 \\
\hline Step 13 & SPE4 (T 23-25 min) & $0-10 \mathrm{~min}$ & $100 / 0$ & SA20-13 \\
\hline Step 14 & SPE3 (T 20-23 min) & $0-10 \mathrm{~min}$ & $100 / 0$ & SA20-14 \\
\hline Step 15 & SPE2 (T 17-20 min) & $0-10 \mathrm{~min}$ & $\mathrm{MeCN} /$ water, $\mathrm{pH}^{\mathrm{e}}$ & SA20-15 \\
\hline \multirow[t]{5}{*}{ Step 16} & SPE13 (T 0-4 min) & $0-4 \min$ & $0 / 100$ & SA20-16 to -23 \\
\hline & \multirow[t]{4}{*}{ Column $2.3^{\mathrm{b}}$} & 4-20 min & 0/100-10/90 & \\
\hline & & $20-40 \mathrm{~min}$ & $10 / 90-60 / 40$ & \\
\hline & & $40-50 \mathrm{~min}$ & $60 / 40-100 / 0$ & \\
\hline & & $50-60 \mathrm{~min}$ & $100 / 0$ & \\
\hline \multirow[t]{4}{*}{ Step 17} & SPE7 (T 0-3 min) & $0-20 \min$ & Water, $\mathrm{pH} 3 / 1 \mathrm{M} \mathrm{NH}^{+} \mathrm{COO}^{-}, \mathrm{pH} 3^{\mathrm{f}}$ & SA20-24 to -33 \\
\hline & \multirow[t]{3}{*}{ Column $2.2^{\mathrm{c}}$} & $20-45 \min$ & $100 / 0-85 / 15$ & \\
\hline & & $45-55 \min$ & $85 / 15-0 / 100$ & \\
\hline & & & $0 / 100$ & \\
\hline
\end{tabular}

${ }^{\mathrm{a}} \mathrm{T}$ : Trapping time for the eluents from $1^{\text {st }}$ separation column, ${ }^{\mathrm{b}}$ Column 2.3 : Carbo RP HPLC column $(10 \times 250 \mathrm{~mm}, 5 \mu \mathrm{m}, 3.5 \mathrm{ml} / \mathrm{min}),{ }^{\mathrm{c}} \mathrm{Col}-$ umn 2.2: Cation exchange HPLC column $(10 \times 250 \mathrm{~mm}, 5 \mu \mathrm{m}, 3.5 \mathrm{ml} / \mathrm{min})$, dSubstances trapped into SPE 2 - SPE6, SPE8 - SPE12 and SPE 14 - SPE18 were not subjected to the second separation, but they were washed out of the SPEs with methanol (flow rate $6 \mathrm{ml} / \mathrm{min}$ ), ${ }^{\text {e}}$ Solvent mixture of acetonitril and water including formic acid $(\mathrm{pH} 3)$, 'Solvent mixture of water including formic acid (pH 3) and Ammonium formate buffer $(\mathrm{pH} 3),{ }^{9}$ The eluents coming from SPEs or $2^{\text {nd }}$ separation columns were collected in 48 deep well by 6-7 ml using an automatic fraction collector, and the fractions were then manually re-arrayed into other 48 deep well plates through monitoring HPLC peaks from UV (254) and RI detectors. 

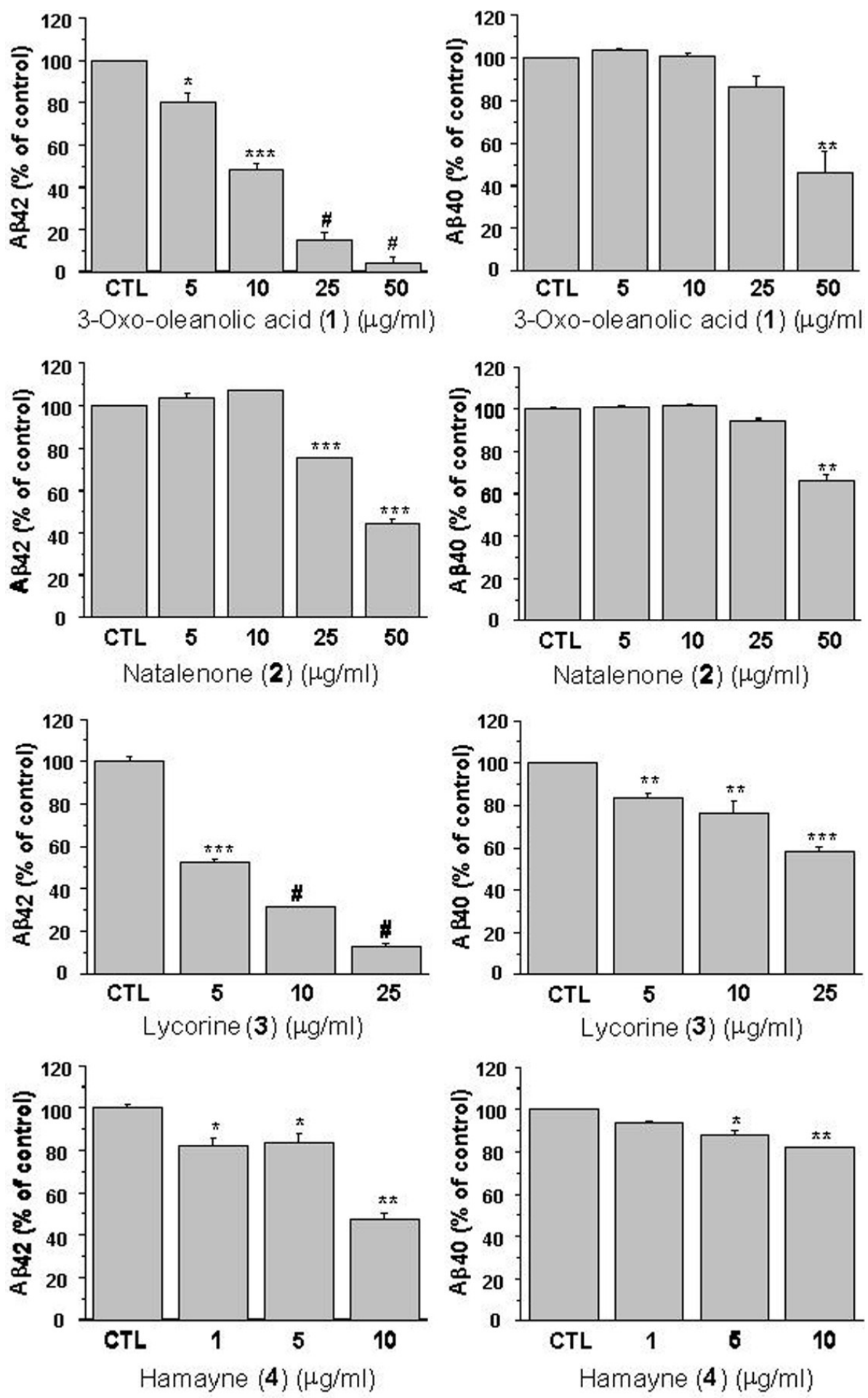

Fig. 2. A $\beta$-lowering effects of 3-oxooleanolic acid (1), natalenone (2), lycorine (3), and hamayne (4). Cells were pre-treated with indicated concentration of each compound for $8 \mathrm{~h}$ before the levels of $A \beta 40$, and $A \beta 42$ in conditioned media were determined using sandwich ELISA as described in Methods. The values \pm s.d. were normalized to the control levels. ${ }^{*} p<0.05$, ${ }^{* *} p<0.01,{ }^{* * *} p<0.001,{ }^{\#} p<0.0001$ with student $t$-test.

(3H, s, $\left.\mathrm{H}_{3}-23\right), 1.16\left(3 \mathrm{H}, \mathrm{s}, \mathrm{H}_{3}-27\right), 1.18\left(1 \mathrm{H}, \mathrm{m}, \mathrm{H}_{2}-19\right), 1.65$ (1H, m, $\left.\mathrm{H}_{2}-19\right), 1.43\left(1 \mathrm{H}, \mathrm{br}\right.$ ddd, J=14.0, 11.0, 7.0 Hz, $\left.\mathrm{H}_{2}-1\right)$, $1.90\left(1 \mathrm{H}, \mathrm{br}\right.$ ddd, $\left.J=14.0,7.0,3.5 \mathrm{~Hz}, \mathrm{H}_{2}-1\right), 2.37(1 \mathrm{H}, \mathrm{ddd}$, $\left.J=16.0,7.0,3.5 \mathrm{~Hz}, \mathrm{H}_{2}-2\right), 2.55(1 \mathrm{H}$, ddd, $J=16.0,11.0,7.0$ $\left.\mathrm{Hz}, \mathrm{H}_{2}-2\right), 2.85(1 \mathrm{H}$, br dd, J=14.0, 4.0, H-18), $5.32(1 \mathrm{H}, \mathrm{br}$ $\mathrm{t}, \mathrm{J}=3.0 \mathrm{~Hz}, \mathrm{H}-12) ;{ }^{13} \mathrm{C}-\mathrm{NMR}\left(125 \mathrm{MHz}, \mathrm{CDCl}_{3}\right) 15.1$ (C-25), 17.0 (C-26), 19.6 (C-6), 21.5 (C-24), 23.0 (C-11), 23.6 (C-16),
25.9 (C-27), 26.5 (C-23), 27.7 (C-15), 30.7 (C-20), 32.2 (C-7), 32.5 (C-22), 33.1 (C-29), 33.9 (C-21), 34.2 (C-2), 36.8 (C-10), 39.2 (C-1), 39.4 (C-8), 41.2 (C-18), 41.8 (C-14), 45.9 (C-19), 46.6 (C-9, C-17), 47.4 (C-4), 55.4 (C-5), 122.4 (C-12), 143.7 (C-13), 183.3 (C-28), 217.6 (C-3).

Natalenone (2): Optically inactive yellow powder; $\mathrm{mp}$. $220^{\circ} \mathrm{C}$; ESI MS m/z 377 [M+H] ${ }^{+} ;{ }^{1} \mathrm{H}$ NMR $\left(500 \mathrm{MHz}, \mathrm{CDCl}_{3}\right.$ ) 
$\delta 2.39\left(3 \mathrm{H}, \mathrm{s}, \mathrm{H}-9^{\prime}\right), 2.42(3 \mathrm{H}, \mathrm{s}, \mathrm{H}-9), 3.00(1 \mathrm{H}, \mathrm{d}, \mathrm{J}=10.5 \mathrm{~Hz}$, $\left.\mathrm{H}_{2}-2 \mathrm{a}\right), 3.04\left(1 \mathrm{H}, \mathrm{dd}, \mathrm{J}=10.5,4.0 \mathrm{~Hz}, \mathrm{H}_{2}-2 \mathrm{~b}\right), 4.18(1 \mathrm{H}, \mathrm{d}, J$ $\left.=4.0 \mathrm{~Hz}, \mathrm{H}-3^{\prime}\right), 4.84(1 \mathrm{H}, \mathrm{s}, \mathrm{OH}), 6.73\left(1 \mathrm{H}, \mathrm{br} \mathrm{s}, \mathrm{H}-6{ }^{\prime}\right), 6.95$ (1H, br s, H-8'), $7.04(1 \mathrm{H}, \mathrm{br} \mathrm{s}, \mathrm{H}-6), 7.47(1 \mathrm{H}, \mathrm{br} \mathrm{s}, \mathrm{H}-8), 11.47$ $(1 \mathrm{H}, \mathrm{s}, \mathrm{OH}), 11.49(1 \mathrm{H}, \mathrm{s}, \mathrm{OH}) ;{ }^{13} \mathrm{C} \mathrm{NMR}\left(125 \mathrm{MHz}, \mathrm{CDCl}_{3}\right) \delta$ 22.4 (C-9), 22.8 (C-9'), 52.5 (C-3'), 54.2 (C-2'), 113.0 (C-4a), 114.9 (C-8'), 119.1 (C-6'), 122.0 (C-8), 124.7 (C-6), 148.8 (C$\left.7^{\prime}\right), 149.5$ (C-7), 162.0 (C-5), 164.0 (C-5').

Lycorine (3): pale yellowish powder; mp. $237^{\circ} \mathrm{C}$; $[\alpha]_{D}^{20}-65^{\circ}$ (c 0.2, EtOH); ESI MS m/z $288[\mathrm{M}+\mathrm{H}]^{+} ;{ }^{1} \mathrm{H}$ NMR $(500 \mathrm{MHz}$, $\left.\mathrm{CD}_{3} \mathrm{OD}\right) \delta$ 2.91-2.74 (2H, m, $\left.\mathrm{H}_{2}-4\right), 2.96(1 \mathrm{H}, \mathrm{br} \mathrm{d}, \mathrm{J}=11.5 \mathrm{~Hz}$, $\mathrm{H}-11 \mathrm{~b}), 3.50\left(1 \mathrm{H}, \mathrm{m}, \mathrm{H}_{2}-5\right), 3.65\left(1 \mathrm{H}, \mathrm{m}, \mathrm{H}_{2}-5\right), 3.84(1 \mathrm{H}, \mathrm{d}, \mathrm{J}$ $=11.5 \mathrm{~Hz} \mathrm{H}-11 \mathrm{c}), 4.24(1 \mathrm{H}, \mathrm{br} \mathrm{s}, \mathrm{H}-2), 4.22(1 \mathrm{H}, \mathrm{d}, \mathrm{J}=14.0 \mathrm{~Hz}$, $\left.\mathrm{H}_{2}-7\right), 4.42\left(1 \mathrm{H}, \mathrm{d}, \mathrm{J}=14.0 \mathrm{~Hz}, \mathrm{H}_{2}-7\right), 4.55(1 \mathrm{H}$, br s, H-1), 5.77 $\left(1 \mathrm{H}\right.$, br s, H-3), $5.99\left(2 \mathrm{H}\right.$, br s, $\left.\mathrm{OCH}_{2} \mathrm{O}\right), 6.84(1 \mathrm{H}, \mathrm{s}, \mathrm{H}-8), 7.00$ (1H, s, H-11).

Hamayne (4): pale yellowish powder; mp. $80^{\circ} \mathrm{C}$; $[\alpha]_{D}{ }^{20}-72^{\circ}$ (c 0.2, EtOH); ESI MS m/z $288[\mathrm{M}+\mathrm{H}]^{+} ;{ }^{1} \mathrm{H}$ NMR $(500 \mathrm{MHz}$, $\left.\mathrm{D}_{2} \mathrm{O}\right) \delta 2.23\left(1 \mathrm{H}, \mathrm{m}, \mathrm{H}_{2}-4\right), 2.34\left(1 \mathrm{H}, \mathrm{m}, \mathrm{H}_{2}-4\right), 3.81(1 \mathrm{H}, \mathrm{br}$, $\left.J=14.0 \mathrm{~Hz}, \mathrm{H}_{2}-12\right), 3.98\left(1 \mathrm{H}, \mathrm{dd}, J=14.0,7.0 \mathrm{~Hz}, \mathrm{H}_{2}-12\right), 4.06$ $\left(1 \mathrm{H}, \mathrm{dd}, J=13.5,4.0 \mathrm{~Hz}, \mathrm{H}_{2}-4\right), 4.25(1 \mathrm{H}, \mathrm{br} \mathrm{d}, J=7.0 \mathrm{~Hz}, \mathrm{H}-11)$, $4.33\left(1 \mathrm{H}, \mathrm{d}, J=15.5 \mathrm{~Hz}, \mathrm{H}_{2}-6\right), 4.47(1 \mathrm{H}, \mathrm{m}, \mathrm{H}-3), 4.76^{\mathrm{a}}(1 \mathrm{H}$, $\left.\mathrm{H}_{2}-6\right), 5.95\left(2 \mathrm{H}\right.$, br s, $\left.\mathrm{OCH}_{2} \mathrm{O}\right), 6.13(1 \mathrm{H}, \mathrm{br} \mathrm{d}, \mathrm{J}=10.5 \mathrm{~Hz}, \mathrm{H}-2)$, $6.23(1 \mathrm{H}, \mathrm{d}, \mathrm{J}=10.5 \mathrm{~Hz}, \mathrm{H}-1), 6.69(1 \mathrm{H}, \mathrm{s}, \mathrm{H}-7), 7.01(1 \mathrm{H}, \mathrm{s}$, $\mathrm{H}-10)^{\mathrm{a}}$ Overlapping signal with a solvent signal.

\section{Measurement of $A \beta$ production}

HeLa cells line stably expressing Swedish mutant form of APP (APPsw) were maintained in DMEM supplemented with $10 \%$ heat-inactivated FBS as described before (Landman et al., 2006). Cells with $60-70 \%$ confluence were pre-incubated with extracts or compounds for $8 \mathrm{~h}$ before the levels of $A \beta 40$ and $A \beta 42$ in conditioned media were determined using sandwich ELISA (Biosource Int.) according to the manufacturer's protocol.

\section{RESULTS}

One step fractionation of the methanol extracts of $E$. crispa subsp. crispa (SA28) and the DCM-MeOH (1:1) extracts of $C$. macowanii (SA20) by the HPLC/SPE/HPLC coupling experiments using the Sepbox system resulted in the isolation of four biologically active subfractions showing inhibition of $A \beta$ production and each containing 1-3 constituents. The subfraction SA20-28 contained predominantly one compound and was analysed by NMR. Subfractions SA28-30, SA28-92 and SA20-17 yielded compounds 1, 2 and 4 via further simple purification steps using semi-preparative HPLC, respectively. Based on the analyses of spectral data including NMR spectra and the literature data, the structures of compounds 1-4 were determined to be 3-oxo-oleanolic acid (1), natalenone (2) isolated from E. crispa subsp. crispa and lycorine (3) and hamayne (4) isolated from C. macowanii. The NMR data of compounds 1-4 were in good agreement with those previously reported in the literature (Ferreira et al., 1977; Evidente et al., 1983; Viladomat et al., 1994; Kwon et al., 1997; Campbell et al., 2000).

Compounds 1-4 lowered the production of $A \beta 42$ with $\mathrm{IC}_{50}$ values of approximately $10,50,5$ and $10 \mu \mathrm{g} / \mathrm{ml}$, respectively (Fig. 2). Lycorine (3) was most effective in reducing $A \beta 42$ levels. 3-Oxo-oleanolic acid (1) also exhibited significant $A \beta 42-$ lowering activity in a dose-dependent manner. The production of $A \beta 40$ was affected by treatment with 3-oxo-oleanolic acid (1) or lycorine (3) only at high concentration. Lycorine (3) was not cytotoxic against cells tested for $A \beta$-lowering effects. Cell viability was not affected by treatment with 3-oxo-oleanolic acid (1) at concentration up to $10 \mu \mathrm{g} / \mathrm{ml}$, whereas $25 \mu \mathrm{g} / \mathrm{ml}$ of 3-oxo-oleanolic acid (1) inhibited cell proliferation by up to $60 \%$ of vehicle-treated cells.

\section{DISCUSSION}

The Sepbox system has been developed to rapidly separate complex mixtures of natural products to almost pure compounds or mixtures of a few substances, which can then be used directly for biological testing. The method is a combination of HPLC and solid phase extn. (SPE) and is coupled into a HPLC/SPE/HPLC unit with 2 semi-preparative pumps, 7 HPLC columns, 18 collecting columns for SPE, a light scattering detector and UV detectors. In Sepbox-250 system used in this study, a crude extract initially separates into a maximum of 18 fractions using a C4 reverse phase HPLC column. These fractions are transferred to 18 SPE columns which include 15 reverse phase SPE, a hydrophilic carbo SPE, a cation exchange SPE and an anion exchange SPE. A fraction adsorbed into each SPE column was subjected to one of six semi-preparative HPLC columns for the second separation, eluting with a different solvents from those of the first fractionation. In general, the second HPLC columns are composed of a C18 RP column for hydrophobic substances, an ordinary C18 RP column, a C18 RP column for hydrophilic substances, a carbo column for oligosaccharides or water soluble substances, a cation exchange column and an anion exchange column. Users can select one of six HPLC columns for a second separation, considering polarity and solubility of each fraction. Fractionation of a crude extract into 100-300 subfractions including many fairly pure compounds is possible through this HPLC/ SPE/HPLC coupling experiments within less than 30 hours.

We were able to rapidly isolate and identify four bioactive compounds namely 3-oxo-oleanolic acid, natalenone, lycorine and hamayne capable of reducing $A \beta$ production, from two South African plants via above mentioned procedure. The biological studies for 3-oxo-oleanolic acid have focused on its anti-tumor effects (Huang et al., 2006). Natalenone is known to be present as a naphthoquinone dimer in isolation studies from Euclea species which is used in African traditional medicines (Ferreira et al., 1977), while lycorine and hamayne possesses antitumor and choline esterase inhibitory effects (Campbell et al., 2000; Houghton et al., 2004; Liu et al., 2009). However, the $A \beta$ reducing effects of the compounds 1-4 have not been reported previously.

$A \beta$ is produced by sequential proteolytic cleavages of the $\beta$ amyloid precursor protein (APP) by a set of membrane-bound proteases termed $\beta$-secretase and $\gamma$-secretase (Iwatsubo et al., 1994; Scheuner et al., 1996). Heterogeneous $\gamma$-secretase cleavage at the $C$-terminal end of $A \beta$ produces two major isoforms of $A \beta, A \beta 40$ and $A \beta 42$. While $A \beta 40$ is the predominant cleavage product, the less abundant $A \beta 42$ represents a longer and more amyloidogenic form of $A \beta$. Moreover, increased cerebrocortical $A \beta 42$ appears to closely correlate with synaptic dysfunction associated with AD (España et al., 2010). The biological study on the action mechanism of compounds 1-4 
is in progress.

In summary, our investigation of bioactive principles of two South African plants for the development of $A \beta$ reducing agents using the Sepbox system resulted in the rapid identification of four bioactive compounds reducing $A \beta$ production, for which their structures were determined as 3-oxo-oleanolic acid, natalenone, lycorine and hamayne based on NMR and MS data. 3-Oxo-oleanolic acid and lycorine exhibited significant reducing effects of $A \beta 42$ production in a dose dependent manner. This result demonstrates how biologically active constituents can be isolated and identified rapidly from plants extracts using an automated HPLC/SPE/HPLC coupling system.

\section{ACKNOWLEDGMENTS}

This study was supported by the Korea Institute of Science and Technology institutional program, grant numbers 2Z0343A.

\section{REFERENCES}

Áurea Cruz Costa, M., Lopes, M. H., Margarida, I. P., Ferreira, M. A. and Alves, A. C. (1976) Naphthaquinones and triterpenoids of Euclea divinorum. Phytochemistry 15, 829.

Campbell, W. E., Nair, J. J., Gammon, D. W., Codina, C., Bastida, J., Viladomat, F., Smith, P. J. and Albrecht, C. F. (2000) Bioactive alkaloids from Brunsvigia radulosa. Phytochemistry 53, 587-591

Clarkson, C., Stærk, D., Hansen, S. H., Smith, P. J. and Jaroszewski, J. W. (2006) Discovering new natural products directly from crude extracts by HPLC-SPE-NMR: Chinane diterpenes in Harpagophytum procumbens. J. Nat. Prod. 69, 527-530.

Duri, Z. J., Scovill, J. P. and Huggins, J. W. (1994) Activity of a methanolic extract of Zimbabwean Crinum macowanii against exotic RNA viruses in vitro. Phytother. Res. 8, 121-122.

España, J., Valero, J., Miñano-Molina, A. J., Masgrau, R., Martín, E., Guardia-Laguarta, C., Lleó, A., Gimínez-Llort, L., RodríguezAlvarez, J. and Saura, C. A. (2010) $\beta$-Amyloid disrupts activity-dependent gene transcription required for memory through the CREB coactivator CRTC1. J. Neurosci. 30, 9402-9410.

Evidente, A., Rosaria Cicala M, Giudicianni, I., Randazzo, G. and Riccio, R. (1983) ${ }^{1} \mathrm{H}$ and ${ }^{13} \mathrm{C}$ NMR analysis of lycorine and $\alpha$-dihydrolycorine. Phytochemistry 22, 581-584.

Ferreira, M. A., Alves, A. C., Cruz Costa, M. and Paul, M. I. (1977). Naphthoquinone dimers and trimers from Euclea natalensis. Phytochemistry 16, 117-120.

Gundidza, M. (1986) Screening of extracts from Zimbabwean higher plants II: Antifungal properties. Fitoterapia 57, 111-114.

Harvey, A. L. (2007) Natural poducts as a screening resource. Curr. Opin. Chem. Biol. 11, 480-484.

Houghton, P. J., Agbedahunsi, J. M. and Adegbulugbe, A. (2004) Choline esterase inhibitory properties of alkaloids from two Nigerian
Crinum species. Phytochemistry 65, 2893-2896.

Huang, D., Ding, Y., LI, Y., Zhang, W., Fang, W. and Chen, X. (2006) Anti-tumor activity of a 3-oxo derivative of oleanolic acid. Cancer Lett. 233, 289-296.

Iwatsubo, T., Odaka, A., Suzuki, N., Mizusawa, H., Nukina, N., and Ihara, Y. (1994) Visualization of $A \beta 42(43)$ and $A \beta 40$ in senile plaques with end-specific $A \beta$ monoclonals: evidence that an initially deposited species is Aß42(43). Neuron. 13, 45-53.

John, J. E. (2009) Natural products-based drug discovery: some bottlenecks and considerations. Curr. Sci. 96, 753-754.

Joubert, A., van der Kooy, F., Meyer, J. J. M. and Lall, N. (2006) HPLC in the comparative study of the content of naphthoquinones (quinonoid constituents) in Euclea species of South Africa. Chromatographia 64, 399-403.

Kwon, H. C., Lee, K. R. and Zee, O. P. (1997) Cytotoxic constituents of Pilea mongolica. Arch. Pharm. Res. 20, 180-183.

Lall, N. and Meyer, J. J. (2000) Antibacterial activity of water and acetone extracts of the roots of Euclea natalensis. J. Ethnopharmacol. 72, 313-316.

Landman, N., Serban, G., Shin, S. Y., Kang, M. S., Chung, S. and Kim, T. W. (2006) Presenilin mutations linked to familial Alzheimer's disease cause an imbalance in phosphatidylinositol 4,5-bisphosphate metabolism. Proc. Natl. Acad. Sci. 103, 19524-19529.

$\mathrm{Li}$, J. W. H. and Vederas, J. C. (2009) Drug discovery and natural products: end of an era or an endless frontier? Science 325, 161-165.

Lim, H. J., Kim, Y. K. and Sheen, Y. Y. (2006) A correspondence between aging-related reduction of neprilysin and elevation of $A \beta-42$ or $\gamma$-secretase activity in transgenic mice expressing NSE-controlled APPsw or human mutant presenilin-2. Biomol. Ther. 14, 106-109.

Liu, X. S., Jiang, J., Jiao, X. Y., Wu, Y. E., Lin, J. H. and Cai, Y. M. (2009) Lycorine induces apoptosis and down-regulation of Mcl-1 in human leukemia cells. Cancer Lett. 274, 16-24.

Nair, J. J., Machocho, A. K., Campbell, W. E., Brun, R., Viladomat, F., Codina, C. and Bastida, J. (2000) Alkaloids from Crinum macowanii. Phytochemistry 54, 945-950.

Pretorius, J. C., Magama, S. and Zietsman, P. C. (2003) Purification and identification of antibacterial compounds from Euclea crespa subsp. crispa (Ebenaceae) leaves. S. Afr. J. Bot. 69, 579-586 [CAN 141:203261].

Scheuner, D., Eckman, C., Jensen, M., Song, X., Citron, M., Suzuki, N., Bird, T. D., Hardy, J., Hutton, M., Kukull, W., Larson, E., LevyLahad, E., Viitanen, M., Peskind, E., Poorkaj, P., Schellenberg, G., Tanzi, R., Wasco, W., Lannfelt, L., Selkoe, D. and Younkin, S. (1996) Secreted amyloid beta-protein similar to that in the senile plaques of Alzheimer's disease is increased in vivo by the presenilin 1 and 2 and APP mutations linked to familial Alzheimer's disease. Nat. Med. 2, 864-870.

Schiaffella, F., Fratini, L., Mezzetti, T. and Bellavita, V. (1975) Pentacyclic triterpenoids of Euclea natalensis. Phytochemistry 14, 584585.

Viladomat, F., Bastida, J., Codina, C., Campbell, W. E. and Mathee, S. (1994) Alkaloids from Brunsvigia josephinae. Phytochemistry 35 , 809-812.

Walsh, D. M., and Selkoe, D. J. (2007) A beta oligomers - a decade of discovery. J. Neurochem. 101, 1172-1184. 